\title{
Changes in the conduct of administrative proceedings in the scope of cadaster database
}

\author{
Ewa Sudol ${ }^{1, *}$ \\ ${ }^{1}$ Wrocław University of Science and Technology, Faculty of Geoengineering, Mining and Geology, 27 Wyb. Wyspiańskiego St., \\ 50-370 Wrocław, Poland
}

\begin{abstract}
One of the components of the national spatial information infrastructure database (National Geographic Information System) at the district level is the records database of land and buildings. It is a state register that contains databases related to space and procedures and techniques for collecting, updating, processing and sharing information. A legal system regulating the procedures for keeping, updating and making available subject and object information included in the cadastres database is determined by the proper functioning of the land and buildings register (as part of the geodetic resource). The basis of department work in the field of keeping land and buildings records are primarily provisions of the Codex of Administrative Procedure of the Geodetic and Cartographic Law and regulations in the register of land and buildings. On 1 June 2017, a new Codex of Administrative Procedure came into force. In this paper have been presented the most important changes in conducting of administrative procedures in the field of geodesy at the district level after the aforementioned legal amendment. This paper touched the topics related to, among others, issued principle of resolving doubts in favor of the party (Article 7a), silent settlement of the case (Article 122a), administrative simplified proceedings (Chapter 14), appeal proceedings (Chapter 10). There have been presented examples of the most frequently conducted cases in the field of land and buildings registration in district country with particular emphasis on changes introduced by the latest legal amendments in connection with detailed regulations. The author focused on the logical interpretation of legal changes in order to show the problems connected with their application in practice (from the point of view of the proceedings and local government administration).
\end{abstract}

\section{Law basis for updating the cadaster database}

Spatial information refers to the location of the object field. The part of this data used by individuals and institutions, for example for investment purposes and ownership management. For the area of the country, a database is established and maintained in the ICT system, including spatial data sets of the spatial information infrastructure, regarding land and building registers. Data sets collected in databases constitute the basis of the national system of information about the area, which is a component of the spatial information infrastructure referred to in Article. 3 point 2 of the Act of March 4, 2010 on the infrastructure of spatial information [1]. The part of the information is collected and stored in the Country Center for Geodetic and Cartographic Documentation. These data allow public entities, entrepreneurs and citizens with easy access to reliable, complete and current information about real estate.

The proper functioning of data and its continuous use forces the need for continuous updating. This process is governed by the provisions of the Geodetic and Cartographic Law Act and the Ordinance of the Minister of Regional Development and Construction regarding land and building registers, stating that it is the task of the mayor to keep records to maintain the inventory in the state of news that is, compliance with the documents and source materials available to the body and periodic verification of registration data. Changes in databases are carried out ex officio or at the request of a party. An example of proceedings initiated at the request of the parties may be references to changes made to the database of land and buildings as part of the modernization (allegations of the entered data) conducted on the basis of article 24a of the Act [1], changes introduced on the basis of technical operators prepared by authorized surveyors (in the absence of the owner's signature), refusal to release data from a descriptive part of the land and building registry database or to enter data into the database or in the field of the classification of land Soil. Proceedings conducted ex officio at district level are most often carried out in the scope of changing this information resulting from legal regulations, materials of the resource, and detection of erroneous information, at the request of the owners or owners of land on the principle of self-possession. The legal basis of the proceedings is primarily Article 22 section 1 of the Act of May 17, 1989. Geodetic and

* Corresponding author: ewa.sudol@pwr.edu.pl 
cartographic law (Dz.U.2016.1629 i.e., 2016.10.06 with amendments) [1], 47 paragraph 3 of the Ordinance of the Minister of Regional Development and Construction from March 29, 2001. on the registration of lands and buildings (Dz.U.2016.1034 from 2016.07.15) [2] and Article 104 of the Act of 14 June 1960. The Code of Administrative Procedure (consolidated text, Dz.U.2017.1257 from 2017.06.27) [3]. In accordance with the judgments of the Supreme Administrative Court of November 19, 1999, reference number II SA1384 / 99, dated 20 August 1998, Ref. II SA 766/98, the provisions of the Geodetic and Cartographic Law Act do not provide legal grounds for shaping ownership relations and related rights and obligations. The body running the custodial survey is not entitled to settle matters relating to property ownership [4].

The information contained in the land and building register is updated by means of material and technical activity on the basis of legal regulations, entries in land and mortgage registers, final court decisions, and in cases related to the European Certificate of Succession court rulings, final administrative decisions, notarial deeds, certificates of inheritance and European declarations of inheritance, building declarations, entries in other public registers, the application of the interested registration entity and the geodetic documentation indicated in the application, adopted to the state geodetic and cartographic resource, if the change requested includes information collected in the land and building register for real estate in the exclusive jurisdiction of the applicant or applicants, by way of an administrative decision - in other cases (Article 24) [1]. The legal foundation for administrative proceedings regarding the updating of cadaster databases is the amended Code of Administrative Procedure. The provisions of the abovementioned act normalize the work schedule carried out in district offices (Fig. 1).

The result of the high detail of decision bases is their high volatility, which forces the construction of websites to ensure a systematic and continuous data update. The Spatial Information Infrastructure Act, which is - inter alia - the implementation of the EU directive "INSPIRE" into Polish law, obligates to provide IT access to databases (including geodetic databases) [5]. At the same time, it enforces the computerization of the resource. This way of providing spatial information means that consumers of this information become verifying its correctness, compliance with the actual and legal status as well as timeliness. This, in turn, enforces high quality and credibility of the data.

\section{The time of handling cases. Urgency as a means of challenging inaction and excessive length}

The main objectives of the amendment of the CAP were to streamline and speed up administrative procedures, create a framework for more partner relations between citizens and the administration and ensure the adequacy of administrative penalties for violation of the law. The basic expectation related to the amendment of the law resulted from the need to shorten the time of handling cases.

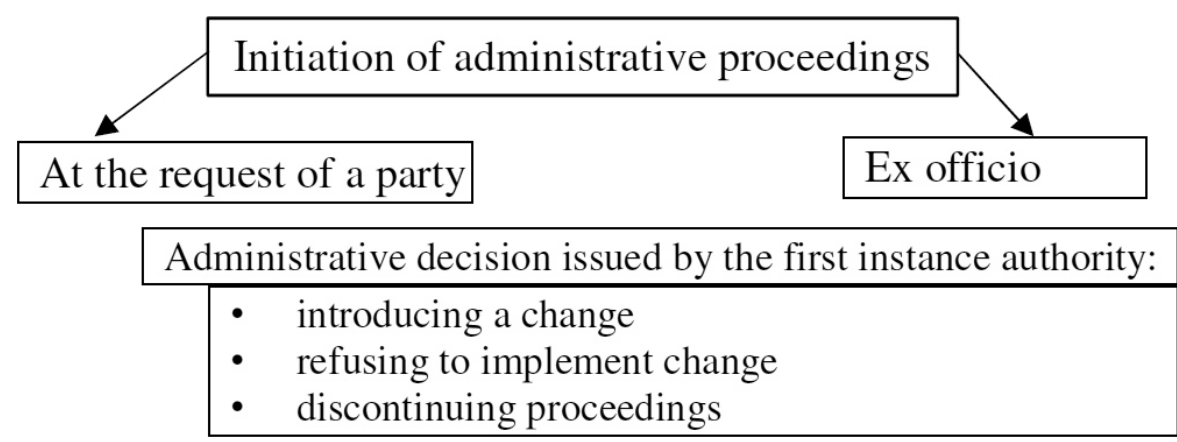

An appeal lodged through the authority of the first instance to the second instance

$$
\begin{aligned}
& \text { Recognition by the body of first instance appeal to be } \\
& \text { justified issuing a new decision to repeal or amend } \\
& \text { the issued decision }
\end{aligned}
$$

Transfer of the appeal together with
the acts to the second instance
authority

Fig. 1. Diagram of administrative proceedings following the amendment of the CAP. 
The amendment to the Administrative Procedure Code introduced the following modifications:

- inactivity of organs or excessive length of proceedings can be challenged in a transparent procedure by means of a reminder (Fig. 2),

- a request for a retrial is optional - without using it you can make a complaint to the administrative court,

- the party may request a second instance authority to issue a decision deciding the case instead of the socalled a cassation decision, that is, forwarding the case to be reconsidered,

- a cassation decision may be appealed to the administrative court in a special accelerated procedure,

- the decision can become final before thanks to the waiver of appeal,

- the framework was introduced procedure of tacit deal with the party's request and simplified procedure, which would reduce formalism in simple cases.

\section{New administration utility}

Pursuant to the amended Code of Administrative Procedure, from 1 June 2017, no appeal to the Provincial Administrative Court can be made against a cassation decision. The amendment of the CAP granted a new appeal to the party - an objection to the decision (Fig. 3).

If in the case there are grounds for issuing a cassation decision, the second instance authority may refer the case back to the first instance. The guidelines of the second instance authority are not formally binding for the first instance authority. An interpretation of the relevant provisions after a detailed determination of the facts of the case and their application remains the responsibility of the first instance authority. Due to the change, if the authority of the second instance notices a mistake in interpreting the law, the first-instance authority will be able to avoid it by reconsidering the case. Another change that has a significant impact on the date of consideration of the case is undoubtedly the possibility of waiving the right to appeal against the decision in accordance with article $127 \mathrm{a}$ CAP. It means that after receiving the decision and using this utility, for example, the investment process can be started more quickly, after the division decision has been received, geodetic works can be carried out without having to wait for the final decision.

A silent solution to the matter is a new utility to accelerate and facilitate the course of proceedings. It lies in the fact that the "silence" of the administrative authority, i.e. no decision after the deadline for settlement of the case shall be deemed to settle this matter in a way that takes into account the whole page request. Silent settlement of the case is not applicable in all proceedings. Only the provision concerning a specific administrative procedure will be the basis for a silent settlement of the matter. The CAP [3] amendment introduced a model procedure in which this will take place at the time when the detailed provisions appear. In the field of geodesy and cartography are no specific guidelines for division offices, which would allow for the use of this utility. A similar legal status applies to the mediation utility. Administrative mediation can be carried out in all matters, the nature of which allows it, i.e. in cases in which there are parties with disputed interests, i.e. Neighborhood disputes or long-lasting disputes between the parties, but also in cases in which we have to deal with a complicated state of affairs. Unfortunately, the use of this tool also requires the adoption of specific provisions.

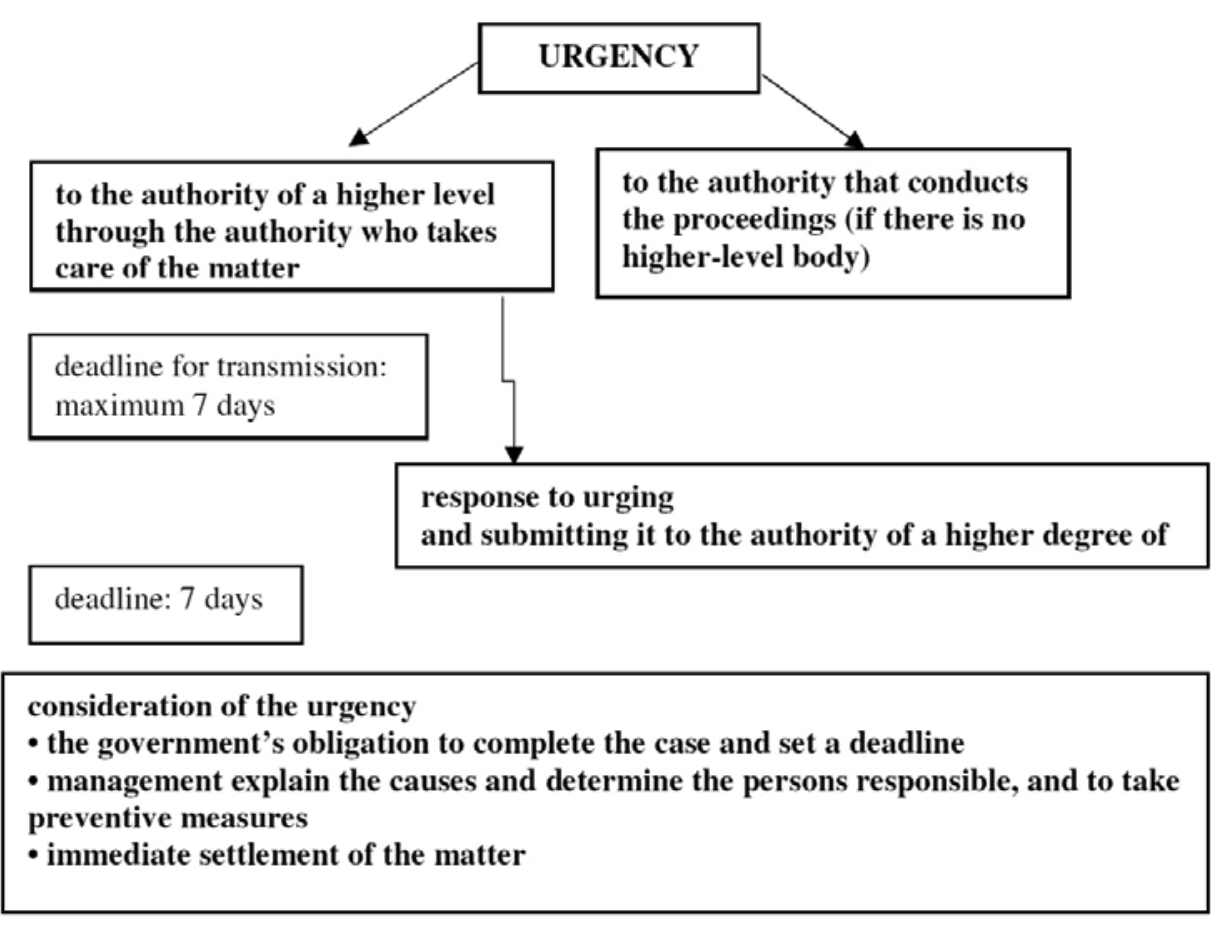

Fig. 2. Diagram of the urgency procedure. 


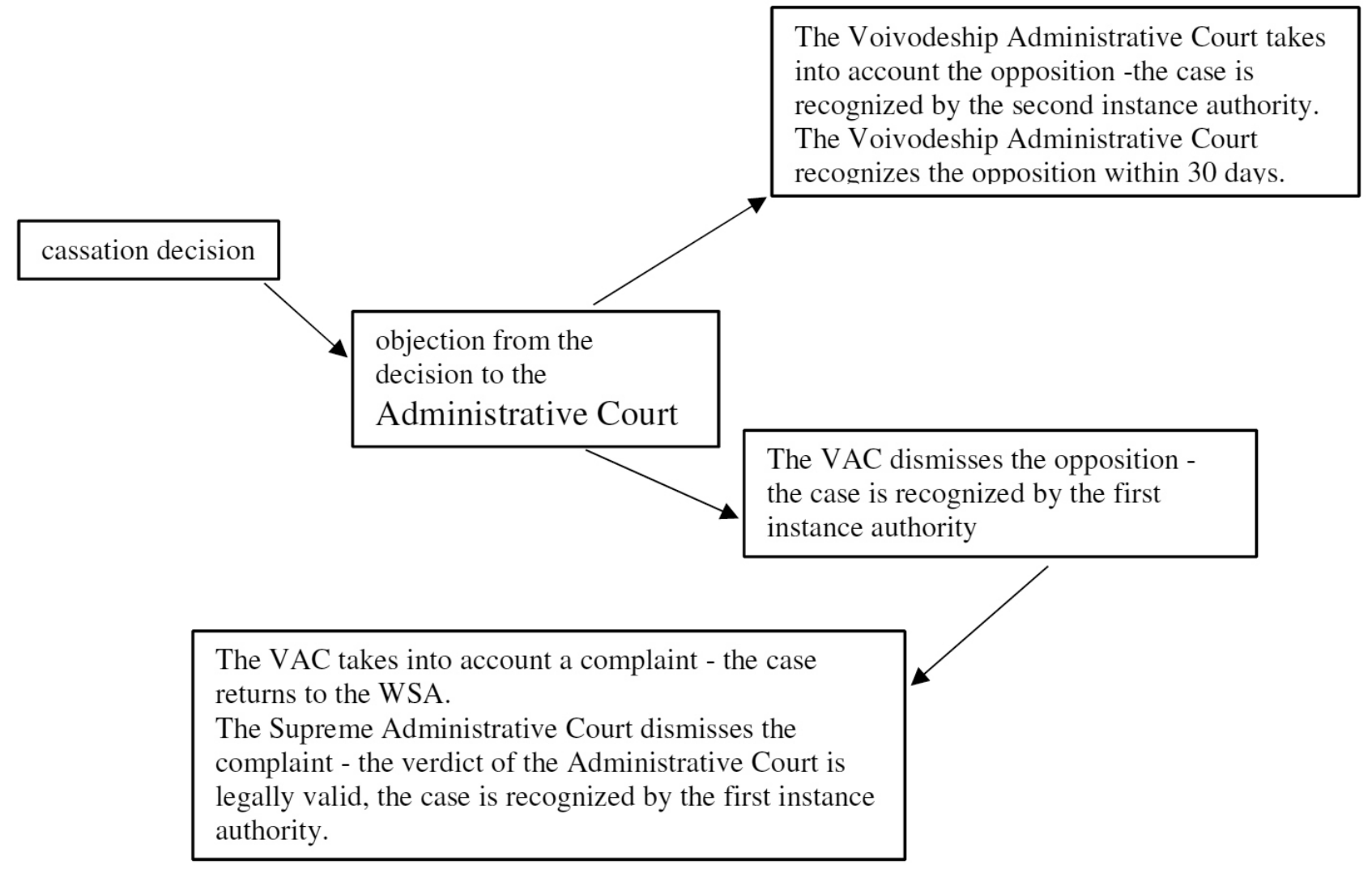

Fig. 3. Opposition to the decision - the course of proceedings [6].

\section{Conclusions}

A modern geodetic resource is based on data bases established and maintained in the ICT system for the entire country. Data update procedures should be as streamlined as possible and as short as possible. Only valid and reliable spatial information allows the use of modern forms of resource sharing, but also new forms of content enrichment services such as high-speed access to data in the resource, the communication process automation contractor - administration. The legal tools described in the amendment to the Code of Administrative Procedure give the opportunity to shorten the time of proceedings related to the updating of geodetic databases. Unfortunately, the current legal status is not complete and specific provisions incompatible with new administrative utilities. There are not precisely formulated range of cases that could be resolved using mediation or in silent mode on your behalf or having simplified administrative proceedings. Experts point out that the above changes were passed very quickly (the government passed them on 7 April), which up to now causes problems with the application of the new regulations.

\section{References}

1. Ustawa $\mathrm{z}$ dnia 17 maja 1989 r. Prawo geodezyjne i kartograficzne, Dz.U.2016.1629 t.j. z dnia 2016.10.06
2. Rozporządzenie Ministra Rozwoju Regionalnego i Budownictwa z dnia 29 marca 2001 r. w sprawie ewidencji gruntów i budynków, Dz.U.2016.1034 t.j. z dnia 2016.07.15

3. Ustawa $\mathrm{z}$ dnia 14 czerwca 1960 r. Kodeks postępowania administracyjnego, Dz.U.2017.1257 t.j. z dnia 2017.06.27

4. Wyroki NSA z dnia 19 listopada 1999r., sygn. II SA1384/99, z dnia 20 sierpnia 1998r., sygn. II SA $766 / 98$

5. Nowoczesny Zasób Geodezyjny i Kartograficzny, Wojewódzka Inspekcja Geodezyjna, Kraków (2015)

6. Nowelizacja Kodeksu Postępowania Administracyjnego, Czego dotyczą zmiany i jak je stosować? Ministerstwo Rozwoju, maj 2017 r. 